\title{
What are the contributions of native plants to the urban ecosystem?
}

\section{Elvan Ender Altay ( $\sim$ elvanender@uludag.edu.tr)}

Bursa Uludağ Üniversitesi: Bursa Uludag Universitesi https://orcid.org/0000-0001-5933-1611

Murat Zencirkıran

Bursa Uludag University: Bursa Uludag Universitesi

\section{Research Article}

Keywords: Bursa (Turkey), Native plants, Sustainability, Urban ecosystem

Posted Date: November 1st, 2021

DOI: https://doi.org/10.21203/rs.3.rs-1035047/v1

License: (c) (1) This work is licensed under a Creative Commons Attribution 4.0 International License. Read Full License 


\section{Abstract}

For the coming years, it is a potential danger that the ecosystems existing in urban areas will be heavily affected, especially under the pressure of climate change. In the face of this danger, it is of great importance to ensure the sustainability of life chains in urban areas. In this context, a good understanding of the natural landscape and the adoption of local species make important contributions to urban areas for sustainable ecosystems. Natural plants interact with all physical and biotic factors in their areas and contribute to the life of natural living communities by easily adapting to environmental conditions. This research was carried out in Bursa (Turkey), which has a rich flora in terms of natural plant taxa. The contributions of 72 woody taxa in Bursa flora to the ecosystem were examined. The relationships that emerged in terms of the criteria examined revealed important results. The existence of a positive relationship between features, which are considered among ecological criteria in terms of contribution to the ecosystem, such as shelter for animals, being a food source, being a food source for humans, attracting butterflies, attracting bees, and preventing erosion, shows that the use of native plants is extremely important for the preservation of ecosystem integrity in urban areas.

\section{Introduction}

With the discovery of agriculture in the Neolithic period, the first activities of people on changing nature began, and in this context, planting seeds of plants, taming animals, settling in certain places and building houses were seen as the first examples of landscaping. The fact that people started to change the landscape through agriculture has led to the emergence of limited nature destruction (Gül, 2000). It is seen that the "Natural Landscape", which has effects from the Stone Age to the present, has decreased with destruction from prehistoric times to the present (Akurgal, 1998). In the following processes, factors such as rapid population growth, the emergence of the industrial revolution, and urbanization caused a rapid increase in the interventions to the natural landscape, which accelerated environmental pollution and started to affect ecosystems negatively. Due to these negativities that have arisen today, people all over the world have begun to worry about "denaturalizing", that is, breaking away from nature or disappearing (Gül, 2000). In order to address these and similar concerns, Miller, Simonds and other researchers suggested 100 years ago that the use of native plants in the landscape is a good option, the evaluation of natural conditions in the natural landscape, the realization of "naturalistic" arrangements based on the recreation of nature rather than artificial arrangements in the design approach.

Wilheim Miller, working at the University of Illinois in 1912, published his work called "Designing in the Prairie Spirit" as a series of articles and gave information about the use of native plants in residential garden, agriculture, parks, roadside design and rural restoration. One of the first practitioners of Miller's ideas was landscape architect Ossian C. Simonds working in the Chicago (SNR, 2011). Parallel to these developments, attempts to minimize human intervention and control in landscape design and applications have increased rapidly. The increase of non-native species is unintentionally or intentionally associated with human activities (Richardson et al., 2000; Garcillan and Martorell, 2021). In particular, natural landscape design and applications, which envisage the promotion of wildlife in cities and the increase of natural areas depending on ecological principles, have started to become popular in Europe and America (Özgüner, 2003).

According to Kendle and Forbes (1997), low-cost sustainable landscapes can be created with the natural landscape style, the real meaning of the landscape can be reflected, a significant contrast to the classical style design experiences can be achieved, the value of the area in terms of environmental protection, environmental education and recreational use can be increased, the public landscape can be valued. This natural landscape style is characterized by diversity of species, structural complexity in plant communities, absence of uniform structure, maximum use of natural elements, especially native species, minimal use of artificial elements and exotic species, minimal human influence in design and implementation, and environmental control. It has begun to be adopted by many of the modern landscape designers and planners who argue that it should be limited (Özgüner, 2003).

The common point of the studies on the ecosystem integrity of natural vegetation, its contribution to biodiversity and its contribution to ensuring habitat continuity is the threat posed to biodiversity by habitat fragmentation. This threat; reveals the necessity of maintaining ecosystem balance and continuity, creating corridors that will allow transitions between natural vegetation and urban landscape, disseminating the use of more intense native plant species in urban areas (Deniz and Şirin, 2005).

This situation is extremely important for sustainable plant designs, defined as "planting or vegetation management that preserves and maintains ecological integrity, encourages the use of native opportunities for plant resources and species selection, and foresees the use of minimum energy and physical resources in production". The basis of this approach is closely related to resource protection and management. The use of native plants in this process is considered more appropriate with considerations such as "the native species' adaptation to the terrain and climatic conditions of the region, providing shelter for many animal species, and their successful performance in problematic areas" (Dunnet and Hitchmough, 1996; Kennedy and Southwood, 1994; Özgüner, 2003).

On the other hand, securing their lives in urban areas where insects and animals have to live as vulnerable to human interactions along with their housing problems requires great efforts. However, despite the challenges of existing in urban environments, many wildlife species have adapted to these systems. It is important to better understand the natural landscape and to adopt native species in order to make ecosystems sustainable in urban areas without breaking the chain of life (Flyger, 1974; Atkinson and Shackleton, 1991; Quinn, 1992; Gliwicz et al., 1994; Gustafson, 1998; Burger et al., 2004; Parker and Nilon, 2008; Perker and Nilon, 2012) this is also a critical tool for habitat identification and conservation of wildlife species (Johnson, 1995; Clergeau et al., 1998; Livingston et al., 2003). 
Native plants are in mutual interaction with all physical and biotic factors in the areas where they are found, easily adapting to environmental conditions, contributing to the life of natural living communities, requiring less care, being a source of shelter and food for wildlife, landscaping, protection and restoration projects. It also has many features such as being among the extremely important alternative sources (Barış, 2002; Deniz and Şirin, 2005; Çorbacı et al., 2017; Eroğlu 2010). In addition to these contributions, exotic plant species contribute almost nothing to the food web (Anoymous, 2019).

However, the existence of natural vegetation has unlimited direct and indirect benefits to the country's economy, and it is a resource in improving the climatic conditions of a country and preventing soil loss in other rural areas, laying the groundwork for scientific research, meeting the raw material and fuel needs of forest products, food, pharmaceutical industry units (Cengiz, 2001). The use of natural vegetation samples in landscape architecture works is an application that is compatible with ecological, economic and aesthetic conditions as well as a landscape design in harmony with nature (Akdoğan, 1972; Atik and Karagüzel, 2007). In designs; With the use of native plants, ecological benefits such as protecting biological diversity, providing a habitat for wildlife species, and creating a healthy plant tissue, economic benefits such as reducing fertilization, spraying and irrigation needs and costs, and aesthetic benefits such as improving environmental quality are provided (Slattery et al., 2003; Atik and Karagüzel, 2007).

In this study, native woody plant taxa in the flora of Bursa province were examined and their contributions to the ecosystem were tried to be revealed.

\section{Material And Methods}

\section{Material}

The woody taxa (Table 1), which are found naturally in the flora of Bursa and evaluated as landscape plants and also have the potential to be evaluated by Zencirkıran (2004), Zencirkıran (2009), were utilised as study material.

Table 1

Native woody taxa evaluated as research material

\begin{tabular}{|c|c|c|}
\hline 1.Pinus pinea $\mathrm{L}$. & 26.Castanea sativa Mill. & 48. Celtis australis $\mathrm{L}$. \\
\hline 2.Pinus brutia Henry. & 27.Quercus robur L. ssp.robur & 49. Tilia argentea Desf.ex.DC. \\
\hline $\begin{array}{l}\text { 3.Pinus nigra Arn. ssp. pallasiana (Lamb.) } \\
\text { Holmboe. }\end{array}$ & 28.Quercus frainetto Ten. 29.Quercus petraea & $\begin{array}{l}\text { 50.Tamarix parviflora DC. } \\
\text { 51.Cercis siliquastrum L. }\end{array}$ \\
\hline $\begin{array}{l}\text { 4.Pinus silvestris } \mathrm{L} \text {. } \\
\text { 5.Abies nordmanniana (Stev.)Spach ssp. } \\
\text { bornmülleriana Mattf. }\end{array}$ & $\begin{array}{l}\text { (Mattuschka) Liebl. ssp. iberica (Steven ex Bieb.) } \\
\text { 30.Quercus hartwissiana Stev infectoria Olivier ssp. }\end{array}$ & $\begin{array}{l}\text { 52. Spartium junceum L. } \\
\text { 53.Chamaecytisus hirsutus (L.) Link. } \\
\text { 54.Chamaecytisus austriacus (L.) Link. } \\
\text { 55.Chamaecytisus pygmaeus (Willd) }\end{array}$ \\
\hline $\begin{array}{l}\text { 6.Juniperus communis ssp. Nana } \\
\text { 7.Juniperus oxycedrus L. 8.Juniperus excelsa L. }\end{array}$ & $\begin{array}{l}\text { infectoria (Reut) Schwarz. 31.Quercus pubescens } \\
\text { Wild. 32.Quercus ithaburensis }\end{array}$ & $\begin{array}{l}\text { Rothm. } \\
\text { 56. Vitex agnus-castus } \mathrm{L} \text {. } \\
\text { 57. Hedera helix } \mathrm{L} \text {. }\end{array}$ \\
\hline 9. Taxus baccata L. & Decne ssp. Macrolepis & 58.Daphne oleoides Schreber \\
\hline 10.Acer campestre L. & Hedge.Yalt. & 59.Daphne pontica L. \\
\hline $\begin{array}{l}\text { 11.Acer platanoides L. 12.Pistacia terebinthus } \\
\text { L. 13.Rhus coriaria L. } \\
\text { 14.Alnus glutinosa L. Gaertn. 15.Carpinus } \\
\text { betulus L. 16.Coryllus avellana L. 17.Cornus } \\
\text { mas L. } \\
\text { 18.Cornus sanguinea L. subsp. } \\
\text { sanguinea } \\
\text { 19.Arbutus unedo L. }\end{array}$ & $\begin{array}{l}\text { 33. Quercus trojana P.B. Webb. } \\
\text { 34. Quercus coccifera L. 35.Quercus hartwissiana } \\
\text { Stev. 36.Laurus nobilis L. 37.Fraxinus ornus L. } \\
\text { 38.Olea europaea L. 39.Jasminum fruticans L. } \\
\text { 40.Phillyrea latifolia L. 41.Platanus orientalis L. }\end{array}$ & $\begin{array}{l}\text { 60.Daphne sericea } \mathrm{L} \text {. } \\
\text { 61.Cistus laurifolius } \mathrm{L} \text {. } \\
\text { 62.Cistus salviifolius } \mathrm{L} \text {. } \\
\text { 63. Cistus creticus } \mathrm{L} \text {. } \\
\text { 64.Euonymous europaeus L. } \\
\text { 65.Pyracantha coccinea M.J.Roem. } \\
\text { 66. Rosa gallica L. } \\
\text { 67. Rosa canina L. } \\
\text { 68.Clematis viticella L. } \\
\text { 69.Clematis cirrhosa L. }\end{array}$ \\
\hline $\begin{array}{l}\text { 20.Arbutus andrachne L. } \\
\text { 21.Erica arborea L. }\end{array}$ & $\begin{array}{l}\text { 42. Salix caprea } \mathrm{L} \text {. } \\
\text { 43. Salix cinerea } \mathrm{L} \text {. }\end{array}$ & $\begin{array}{l}\text { 70. Ruscus aculeatus L. } \\
\text { 71.Styrax officinalis L. }\end{array}$ \\
\hline 22. Vaccinium myrtillus $\mathrm{L}$. & 44. Salix amplexicaulis $\mathrm{L}$. & 72. Viburnum tinus $\mathrm{L}$ \\
\hline 23. Vaccinium uliginosum $\mathrm{L}$. & 45.Populus alba L & \\
\hline 24. Vaccinium arctostaphyllos $\mathrm{L}$. & 46.Populus tremula $\mathrm{L}$. & \\
\hline 25. Fagus orientalis & 47.UImus glabra L. & \\
\hline
\end{tabular}


Bursa, chosen as the study area and the fourth largest city of Turkey in terms of population, is located in the south of the Marmara Region, between $39^{\circ}$ $30^{\prime}-40^{\circ} 37^{\prime}$ north latitudes and $28^{\circ} 06^{\prime}-29^{\circ} 58^{\prime}$ east longitudes. It is surrounded by Bilecik and Sakarya in the east, Kocaeli, Yalova, Istanbul and the Marmara Sea in the north, Kütahya in the south and Balıkesir in the west (Figure 1) (Zencirkıran et al., 2019). Uludag, which has an altitude of 2543 m and hosts extremely important plant taxa, is located within the borders of Bursa province. On the northwest skirts of Uludağ is the Bursa Plain, where the city spreads. The hottest months of the city are July - August, and the coldest months are February and March. The annual total precipitation is $736.1 \mathrm{~mm}$ and the average relative humidity is around $69 \%$. The Mediterranean climate is dominant in Bursa, which has a coast to the Marmara Sea, with warm and dry summers and mild and rainy winters. As you move away from the sea, a semi-terrestrial climate is observed in the interior (Korukçu and Arıcl, 1986 ; Zencirkıran, 2004; Ender and Zencirkıran, 2017; Zencirkıran et al. 2019).

\section{Methods}

Using sources such as Davis (1965-1985), Dirr (1998), Hillier (1998), Zencirkıran (2004), Zencirkıran (2009), Zencirkıran (2013), Sarah et al. (2014), FloridaFriendly Landscaping ${ }^{\text {TM }}$ Guide (2015), Zencirkıran et al (2019) Gardening with Native Plants, (2012), Native Plants for your Landscape (2012) Native and Adapted Landscape Plants (2009), Akkemik (2020), the criteria of taxa under the headings of "contributions to the ecosystem" and "ecological demands" were put forward.

The contributions of taxa to the ecosystem were evaluated within the scope of ecological criteria (creation of natural habitat (shelter), food source for animals, food source for humans, butterfly attraction, bee attraction (pollination), erosion prevention) and aesthetic criteria (autumn coloration, flowering period, form. Ecological demands of taxa were examined under the headings of water, soil and light demands.

All data obtained were evaluated using the SPSS 22 for Windows package program (IBM Corp Released 2013). Pearson correlation analysis was performed in order to determine the direction and strength of the relationships that may exist between the criteria (Miles and Banyard, 2007; Öztuna et al., 2008; Choi et al., 2010; Sheskin, 2011). Since all plants have the ability to create a natural habitat (shelter), the criterion of shelter was excluded, considering that it would prevent a statistically significant result in terms of relations between criteria.

On the other hand, flower colors were not taken into consideration, considering that misleading results could be obtained regarding bees within the scope of the situations presented by some researchers such as Parker et al. (1987), Arbuckle et al. (2001), Willmer, and Stone (2004); Willmer (2011), Lunau et al. (1996), Spaethe et al. (2001), Manning (1956), Free (1970), Waser and Price (1985), Dafni and Giurfa (1999), Lunau (2000), Lunau, (2006), Hempel de Ibarra and Vorobyev (2009).

\section{Results}

Within the scope of the research, it was determined that $38.9 \%$ of the 72 woody taxa naturally found in Bursa flora and evaluated were evergreen and $61.1 \%$ were deciduous taxa. It was determined that $42 \%$ of the taxa had moderate water demand, $51 \%$ clayey-sandy-loam soil demand, and $51 \%$ were suitable to be kept in sun-half shade environments (Figures 2, 3 and 4).

The findings of the ecological and aesthetic criteria examined in terms of the contribution of taxa to the ecosystem are given in Table 2 and Figures 5 and 6.

Table 2

Distribution of taxa according to ecological and aesthetic criteria

\begin{tabular}{|c|c|c|c|c|c|c|c|}
\hline & & \multirow{2}{*}{\multicolumn{5}{|c|}{$\begin{array}{l}\text { Ecological } \\
\text { Criteria }\end{array}$}} & \multirow[t]{2}{*}{ Eesthetic Criteria } \\
\hline & & & & & & & \\
\hline & & $\begin{array}{l}\text { Food source for } \\
\text { animals }\end{array}$ & $\begin{array}{l}\text { Food source for } \\
\text { humans }\end{array}$ & $\begin{array}{l}\text { Butterfly } \\
\text { Attraction }\end{array}$ & $\begin{array}{l}\text { Bee } \\
\text { Attraction }\end{array}$ & $\begin{array}{l}\text { Erosion } \\
\text { Prevention }\end{array}$ & $\begin{array}{l}\text { Autumn } \\
\text { coloration }\end{array}$ \\
\hline \multirow[t]{2}{*}{ Number } & + & 29 & 19 & 29 & 44 & 36 & 16 \\
\hline & - & 43 & 53 & 43 & 28 & 36 & 56 \\
\hline \multirow[t]{2}{*}{ Percent } & + & $40,3 \%$ & $26,4 \%$ & $40,3 \%$ & $61,1 \%$ & $50,0 \%$ & $22,2 \%$ \\
\hline & - & $59,7 \%$ & $73,6 \%$ & $59,7 \%$ & $38,9 \%$ & $50,0 \%$ & $77,8 \%$ \\
\hline
\end{tabular}

The mean values and standard deviations of the criteria are given in Table 3, and the relations between the criteria are given in Table 4 as a result of the correlation analyzes made in terms of the dendrological characteristics and ecological demands of the taxa and their contributions to the ecosystem within the framework of ecological and aesthetic criteria. 
Table 3

The mean values and standard deviations of the criteria

\begin{tabular}{|llll|}
\hline Criterion & Mean & Std.Deviations & Total \\
\hline Leaf Characteristic & 1,61 & 0,491 & 72 \\
\hline Water Demand & 2,75 & 0,931 & 72 \\
\hline Soil Demand & 3,38 & 1,347 & 72 \\
\hline Light Demand & 1,71 & 0,701 & 72 \\
\hline Food Source for Animals & 0,40 & 0,494 & 72 \\
\hline Food Source for Humans & 0,26 & 0,444 & 72 \\
\hline Butterfly Attraction & 0,40 & 0,494 & 72 \\
\hline Bee Attraction & 0,61 & 0,491 & 72 \\
\hline Erosion Prevention & 0,50 & 0,504 & 72 \\
\hline Autumn Coloration & 0,22 & 0,419 & 72 \\
\hline Flowering Period & 2,11 & 1,469 & 72 \\
\hline Form & 2,71 & 0,999 & 72 \\
\hline
\end{tabular}

Table 4

Relationship between criteria

\begin{tabular}{|c|c|c|c|c|c|c|c|c|c|c|c|}
\hline & $\begin{array}{l}\text { Water } \\
\text { Demand }\end{array}$ & $\begin{array}{l}\text { Soil } \\
\text { Demand }\end{array}$ & $\begin{array}{l}\text { Light } \\
\text { Demand }\end{array}$ & $\begin{array}{l}\text { Food } \\
\text { Source } \\
\text { for } \\
\text { Animals }\end{array}$ & $\begin{array}{l}\text { Food } \\
\text { Source } \\
\text { for } \\
\text { Humans }\end{array}$ & $\begin{array}{l}\text { Butterfly } \\
\text { Attraction }\end{array}$ & $\begin{array}{l}\text { Bee } \\
\text { Attraction }\end{array}$ & $\begin{array}{l}\text { Erosion } \\
\text { Prevention }\end{array}$ & $\begin{array}{l}\text { Autumn } \\
\text { Coloration }\end{array}$ & $\begin{array}{l}\text { Flowering } \\
\text { Period }\end{array}$ & Form \\
\hline $\begin{array}{l}\text { Leaf } \\
\text { Characteristic }\end{array}$ & $.493^{\star *}$ & 0,160 & $-0,048$ & 0,074 & $-0,040$ & 0,074 & $-0,052$ & $-0,228$ & $.426^{* *}$ & 0,041 & $-0,005$ \\
\hline $\begin{array}{l}\text { Water } \\
\text { Demand }\end{array}$ & & $.289^{*}$ & 0,038 & 0,100 & 0,026 & 0,038 & $-.247 *$ & $-0,180$ & 0,181 & $-0,072$ & 0,133 \\
\hline Soil Demand & & & $-0,091$ & $-0,082$ & 0,044 & 0,193 & $-.330 * \star$ & $-.446^{* *}$ & 0,125 & 0,050 & 0,124 \\
\hline $\begin{array}{l}\text { Light } \\
\text { Demand }\end{array}$ & & & & $-0,063$ & $-0,066$ & $-0,103$ & $-0,212$ & $-0,020$ & $-0,016$ & $-0,119$ & 0,058 \\
\hline $\begin{array}{l}\text { Food Source } \\
\text { for Animals }\end{array}$ & & & & & $.536^{\star *}$ & 0,134 & $.248 *$ & 0,142 & 0,038 & $.326 * \star$ & $-0,101$ \\
\hline $\begin{array}{l}\text { Food Source } \\
\text { for Humans }\end{array}$ & & & & & & $.344^{* *}$ & $.284^{*}$ & 0,158 & $-0,017$ & 0,149 & 0,112 \\
\hline $\begin{array}{l}\text { Butterfly } \\
\text { Attraction }\end{array}$ & & & & & & & $.481^{\text {** }}$ & $-0,198$ & $-0,098$ & $.539 * \star$ & $-0,101$ \\
\hline $\begin{array}{l}\text { Bee } \\
\text { Attraction }\end{array}$ & & & & & & & & $.285^{*}$ & $-0,190$ & $.412^{\star \star}$ & $-.292^{*}$ \\
\hline $\begin{array}{l}\text { Erosion } \\
\text { Prevention }\end{array}$ & & & & & & & & & $-0,067$ & $-0,152$ & $-0,042$ \\
\hline $\begin{array}{l}\text { Autumn } \\
\text { Coloration }\end{array}$ & & & & & & & & & & $-0,041$ & 0,022 \\
\hline $\begin{array}{l}\text { Flowering } \\
\text { Period }\end{array}$ & & & & & & & & & & & $-0,218$ \\
\hline
\end{tabular}

A significant positive correlation was determined at the level of $1 \%$ between the leaf characteristics of taxa and their water demands. And also $1 \%$ significant positive correlation was determined between the leaf characteristics of the taxa and the autumn coloration, significant positive correlation at the level of $5 \%$ between the water demand and soil demand of taxa, significant negative at the level of $1 \%$ between soil demand and erosion prevention, significant negative at the level of $1 \%$ between soil demand and bee attraction feature, $1 \%$ significant positive correlation between being a food source for animals and a food source for humans and flowering period, significant positive correlation at the level of $5 \%$ between being a source of food for animals and bee attraction, $1 \%$ significant positive correlation between being a food source for humans and attracting butterflies and there is significant positive correlation at the $5 \%$ level between bee attraction. $1 \%$ positive correlation was determined between attracting butterflies and attracting bees and also between butterfly attraction and flowering time. There is $1 \%$ significant positive between bee attraction and flowering time. A significant positive correlation was determined at the $5 \%$ level between bee attraction and erosion prevention. There is a significant negative correlation at the $5 \%$ level with bee attraction and water demand. On the other hand, a significant negative correlation at the level of $5 \%$ was determined between bee attraction and form. 


\section{Discussion And Conclusions}

For the coming years, it is a potential danger that the ecosystems existing in our urban areas will be affected, fragmented and even destroyed, especially under the pressure of climate change. It is clear that the form and severity of the impact that this danger may cause will differ on the basis of countries and even cities. As a matter of fact, Bastin et al. (2019), "due to the possible effects of global warming in the coming years, more than $77 \%$ of the cities in the world may experience a change towards the climatic conditions of another major city by 2050 . They also stated that $22 \%$ of them could switch to climatic conditions that are not currently available for any major city in the world" and that "the climate of Bursa city will be met with an average temperature increase of $2.4^{\circ} \mathrm{C}^{\prime \prime}$.

It is foreseen that this process that can be experienced will affect especially urban areas and ecosystems intensely. It is of great importance to ensure sustainability without breaking the existing chain of life in these areas. In this context, a good understanding of the natural landscape for sustainable ecosystems in urban areas, the adoption of native species (Flyger, 1974; Atkinson and Shackleton, 1991; Quinn, 1992; Gliwicz et al., 1994; Gustafson, 1998; Burger et al., 2004; Parker and Nilon, 2008; Perker and Nilon, 2012), for urban spaces where native species can easily adapt (Kowarik et al., 2013; Sjöman et al., 2016), the selection of suitable design plants by considering ecological concerns (Zencirkıran and Seyidoğlu Akdeniz, 2017) and the use of natural vegetation samples (Akdoğan 1972, Atik and Karagüzel, 2007) provide important contributions.

On the other hand, native plants can adjust themselves to various sites, such as wet or dry, sun or shade, high or low fertility soils and acidic or calcareous soils. If the usage is appropriate, native plants might; 1 . be of an added contribution to wildlife, 2 . require less maintenance, 3 . provide a four-season use, 4. be a good option for an irregular landscape planning, 5. preserve the native varieties and the maintain the biodiversity, and 6 . add a local touch to the landscape (Sheaffer and Rose, 1998).

It is very rich in native plant taxa and has 1808 vascular plant taxa (Anonymous 2019). In this study, in which the ecological and aesthetic contributions of 72 woody taxa in Bursa flora to the ecosystem were examined, the relationships that emerged in terms of the criteria examined revealed important results.

The existence of a positive relationship between features such as shelter for animals, being a food source, being a food source for humans, attracting butterflies, attracting bees, and preventing erosion, which are considered among ecological criteria in terms of contribution to the ecosystem, shows that the use of native plants is extremely important for the preservation of ecosystem integrity.

Indeed, Shackleton (2016), McFrederick and LeBuhn (2006), and Frankie et al. (2005) emphasized in their studies that enriching the habitats in urban areas with native plants provides a source of food and shelter for more bird species and bees. Pardee and Philpott (2014), Pawelek et al. (2009) and Frankie et al. (2005) stated that the presence of native plants plays an important role in the preservation of bee presence and diversity in urban ecosystems, while Karin et al. (2007) stated that there are more butterflies in native plants.

However, it has been emphasized that native plants provide critical benefits in preventing erosion and increasing pollination (Darricau, 2018; Elderbrock et al., 2020) and contribute to the ecosystem by increasing biodiversity through their important ecological functions (Kowarik, 2011).

Sustainability of ecosystem integrity, which is tried to be expressed above, is possible with designs made with natural taxa in the flora of that region (Zencirkıran, 2009; Korkut and ark., 2017), where natural resource consumption is minimized. In particular, the sustainability of the designs created with exotic plants, which do not contribute to the wildlife food web (Anoymous, 2019) due to some aesthetic concerns, does not seem possible due to the climate changes and urban pressures that may occur in the coming decades.

As a result; It is thought and recommended to pay attention to these issues that ecosystems in urban areas can be sustainable with design approaches in which the idea that they are the habitat of other living things within a system integrity and native plants and natural resources of that region are preferred. It is recommended to pay attention to these issues in designs in urban areas.

\section{Declarations}

Author's contributions All authors have equal contribution.

Data availability The data that support the findings of this study are

available from the corresponding author, upon reasonable request.

\section{Compliance with ethical standards}

Competing interests The authors have no conflicts of interest to declare that are relevant to the content of this article.

Ethics aprroval Not applicable.

Consent to participate Not applicable.

Consent for publication All the signing authors agree with the version sent and with its publication in Urban Ecosystems

\section{References}


Akdoğan, G., (1972). Orta Anadolu Step Bitki Örtüsünde Bulunan Bazı Otsu Bitkilerin Peyzaj Planlamasında Değerlendirme İmkanları Üzerine Bir Araştırma, Köy İşıri Bakanlığı Yayın No: 198, Toprak Su Genel Müdürlüğü Yayını, Sayı 282, Ankara.

Akkemik, Ü. (2020). Türkiye'nin Bütün Ağaç ve Çalıları. İş Bankası Kültür Yayınları, Sertifıka No:40077, Genel Yayın:4996. İstanbul.1362 s.

Akurgal, E. (1998). Anadolu Kültür Tarihi, Tübitak Yayınları, Ankara.

Anonymous, (2019). Bursa Province 2018 Environmental Status Report. T.R. Bursa Governorship, Provincial Directorate of Environment and Urbanization. 105 s.. Accessed Date: 18.08.2021.

Arbuckle, T., S. Schröder, V. Steinhage and D. Wittmann (2001) Biodiversity Informatics in Action: Identification and Monitoring of Bee Species using ABIS. Proc. 15th International Symposium Informatics for Environmental Protection, Zürich, October pp. 425-430

Atik, M. ve Karagüzel, O. (2007). Peyzaj Mimarlığı Uygulamalarında Su Tasarrufu Olanakları ve Süs Bitkisi Olarak Doğal Türlerin Kullanım Önceliği. Tarımın Sesi TMMOB Ziraat Mühendisleri Odası Antalya Şubesi Yayını, Sayı 15, s. 9-12.

Atkinson, K. T., Shackleton, D. M. (1991). Coyote (Canis latrans) ecology in a rural-urban-environment. The Canadian Field-Naturalist, $105,49-54$.

Barış, M. E. 2002. Yeşil Alan Uygulamalarında Doğal Bitki Örtüsünden Yeterince yararlanıyormuyuz? II. Ulusal Süs Bitkileri Kongresi, $22-24$ Ekim 2002. Antalya

Bastin, J.F., Clark,E., Elliott, T., Hart, S., Hoogen, J., Hordijk, I., Ma, H., Majumder, S., Manoli, G., Maschler, J., Mo, L., Routh, D., Yu, K., Zohner, C. M., Crowther, T. W., (2019). Understanding Climate Change From A Global Analysis Of City Analogues. PLoS ONE 14(7):

e0217592. https://doi.org/10.1371/journal.pone.0217592

Burger, J., Christian, J., Heather, J., Fizgeralk, M., Carlucci, S., Shukla, S., et al. (2004). Habitat use in basking Northern water (Nerodia sipedon) and Eastern garter (Thamnophis sirtalis) snakes in urban New Jersey. Urban Ecosystems, 7(1), 17-27

Cengiz, B. (2001). Batı Karadeniz Bölgesi Doğal Bitki Örtüsünde Peyzaj Uygulamaları Amacına Yönelik Bazı Creataegus L. Taksonlarının Saptanması. (Basılmamış Yüksek Lisans Tezi), Zonguldak Kara Elmas Üniversitesi, Fen Bilimleri Enstitüsü, S:122, Bartın.

Choi, J., Peters, M., Mueller, R.O. (2010). Correlation analysis of ordinal data: fromPearson's r to Bayesian polycoric correlation, Asia Pacific Educ. Rev., 11:459-466, S:460.

Davis P.H. (1965-1985). Flora of Turkey and the East Aegean Islands. Vols. 1-9. Edinburgh Univ. Press, Edinburgh.

Deniz, B., Şirin, U. (2005). Samson Dağı Doğal Bitki Örtüsünün Otsu Karakterdeki Bazı Örneklerinden Peyzaj Mimarlığı Uygulamalarında Yararlanma Olanaklarının İrdelenmesi. Adnan Menderes Üniversitesi Ziraat Fakültesi Dergisi. 2(5):5-12.

Clergeau, P., Savard, J.-P.L., Mennechez, G., Falardeau, G., (1998). Bird abundance and diversity along an urban- rural gradient: a comparative study between two cities on different continents. Condor 100, 413-425.

Çorbacı, Ö. L., Yazgan, M.E., Özyavuz, M., (2017). Kurakçıl Peyzaj (Xeriscape) ve Uygulamaları. 1.Baskı. Karakayalar Matbaa, Uzunköprü-Edirne. (ISBN 978605-030-618-7). $106 \mathrm{~s}$.

Dafni, A. and M. Giurfa (1999) The functional ecology of nectar guides in relation to insect behavior and vision. In Evolutionary theory and processesmodern perspectives. Edited by. Wasser, S., May, R. Klewer. Netherlands, pp 363-383

Darricau, Y., 2018. Planter des arbres pour les abeilles, l'api-foresterie de demain. Editions de Terran.

Dirr, M. A. 1998. Manual of Woody Landscape Plants: Their Identification, Ornamental Characteristics, Culture, Propagation and Uses. Stipes Publising L.L.C. Champaign, Illionis. ISBN: 0-87563- 800-7.,

Dunnett, N., Hfitchmough, J. (1996). Excitement and energy. Landscape Design. 43-46

Elderbrock, E., Enright, C., Lynch, K.A., Rempel, A.R. (2020) A Guide to Public Green Space Planning for Urban Ecosystem Services Land 2020, 9(10), 391; https://doi.org/10.3390/land9100391

Ender, E., Zencirkıran, M. (2017). Researches on Attractive Flowered Natural Woody Plants of Bursa Flora in Terms of Landscape Design. International Journal of Environmental, Chemical, Ecological, Geological and Geophysical Engineering. 11(7):645-650.

Eroğlu, S. (2010). İstanbul Metropolü Dahilindeki Çevre Yollarının Bitkisel Tasarım Açısından İncelenmesi. İstanbul Teknik Üniversitesi Fen Bilimleri Enstitüsü Peyzaj Mimarlığı Anabilim Dalı Yüksek Lisans Tezi. İstanbul.

Florida-Friendly Landscaping ${ }^{\text {TM }}$ Guide to Plant Selection \& Landscape Design

(2015). https://ffl.ifas.ufl.edu/media/fflifasufledu/docs/FYN_Plant_Selection_Guide_2015.pdf

Page $7 / 13$ 
Flyger, V. F. (1974). Tree squirrels in urbanizing environments. In J. H. Noyes, \& D. R. Progulske (Eds.), Wildlife in an urbanizing environment (pp. 235-248). Frankie, G.W., Thorp, R.W., Schindler, M., Hernandez, J., Ertter, B., Rizzardi, M. (2005) Ecological patterns of bees and their host ornamental flowers in two northern California cities. J Kans Entomol Soc 78:227-246

Free, J. B. (1970) The flower constancy of bumble bees. J Anim Ecol 39: 395-402

Garcillan, P. P., Martorell, C. (2021). Time since first record and population density influence range sizes of non-native plants, but also of native plants, in a chronically overgrazed island. Plant Ecology and Evolution 154 (2): 173-182. https://doi.org/10.5091/plecevo.2021.1806

Gardening with Native Plants (2012). Habitat Acquisition Trust. http://www.hat.bc.ca/images/Native-Plant-Guide-for-Web-22.08.2017-2.pdf

Gliwicz, J., Goszczynski, J., \& Luniak, M. (1994). Characteristic features of animal populations under synurbization-the case of the Blackbird and of the Striped Field Mouse. Memorabilia Zoologica, 49, 237-244.

Gustafson, E. J. (1998). Quantifying landscape spatial pattern: What is the state of the art. Ecosystems, 29, 143-156.

Gül, A. (2000). Peyzaj - İnsan İlişkisi ve Peyzaj Mimarlığı. Süleyman Demirel Üniversitesi Orman Fakültesi Dergisi A(1):97-114.

Hempel de Ibarra N. and M. Vorobyev (2009) Flower patterns are adapted for detection by bees. J Comp Physiol A 195: $319-323$.

Hillier, J. (1998). The Hillier Manuel of Trees and Shrubs. Pocket Edition. A David and Charles Book. 928 p.

IBM Corp. Released (2013). IBM SPSS Statistics for Windows, Version 22.0. Armonk, NY: IBM Corp.

Johnson, C.W., (1995). Planning and designing for the multiple use role of habitats in urban/suburban landscapes in the Great Basin. Landsc. Urban Plann. 32, 219-225.

Kendle, A. D., Forbes, S. J. (1997). Urban Nature Conservation: Landscape Management in the Urban Countryside. E \& FN Spon, London.

Kennedy, C. E. J. and Southwood, T. R. E. (1984). The number of insects associated with British trees: a re-analysis. Journal of Animal Ecology, 53: 455478.

Korkut, A., Kiper, T., Topal, T. Ü. (2017). Kentsel Peyzaj Tasarımda Ekolojik Yaklaşımlar. Artium. 5 (1): 14-26.

Korukcu, A., Arıcı, İ. (1986). Bursa Yöresinin Kültürteknik Sorunlarının Çözümüne Illişkin Yapılan Çalışmalar ve Sonuçları. II.Ulusal Kültürteknik Kongresi Bildirileri, Adana.

Kowarik, I., (2011), Novel urban ecosystems, biodiversity, and conservation. Environ. Pollut. 159, 1974-1983.

Kowarik, I., Von der Lippe, M., Cierjacks, A. (2013). Prevalence of alien versus native species of woody plants in Berlin differs between habitats and at different scales Preslia, 85 (2013), pp. 113-132

Livingston ve ark., (2003). A model for assessing wildlife habitats in urban landscapes of eastern Pima County, Arizona (USA). Landscape and Urban Planning 64 (2003) 131-144.

Lunau, K (2000) The ecology and evolution of visual pollen signals. Plant Syst Evo 222: 89-111.

Lunau, K (2006) Stamens and mimic stamens as components of floral colour patterns. Bot Jahrb Syst 127:13-41

Lunau, K., S. Wacht, and L. Chittka. (1996) Colour choices of naïve bumble bees and their implications for colour perception. J Comp Physiol A 178: 47789

Manning, A. (1956) The effect of honey-guides. Behaviour 9:114-139 Mamıkoğlu, N. G. (2020). Türkiye'nin ağaçları ve çalıları. Kırmızı Kedi Yayınevi.

McFrederick, Q.S., LeBuhn, G. (2006) Are urban parks refuges for bumble bees Bombus spp. (Hymenoptera: Apidae)? Biol Conserv 129:372-382.Meffe, G.K. and Carroll, C.R., 1994. Principles of Conservation Principles. Sinauer Associates Inc. Publishers, Sunderland, Massachusetts.

Miles, J., Banyard, P. (2007). Understanding and using statistics in psychology: a practical introduction. Sage.

Native and Adapted Landscape Plants (2009). An earthwise guide for Central Texas. http://counties.agrilife.org/williamson/files/2014/08/Native-andAdaptive-Plants.pdf

Native Plants for your Landscape (2012). Missouri Department Of Conservation. https://mdc.mo.gov/sites/default/files/2020-

04/nativeplantsrevision_2012_07web.pdf 
Özgüner, H. (2003). Doğal Peyzajın İnsanların Psikolojik Ve Fiziksel Sağlığı Üzerine Etkileri. Süleyman Demirel Üniversitesi Orman Fakültesi Dergisi $A(2): 97-107$.

Öztuna D., Elhan A. H., Kurşun N. 2008. Sağlık Araştırmalarında Kullanılan İlişki Katsayıları, Turkiye Klinikleri J Med Sci, 28:160-165

Pardee, G.L., Philpott, S. M. (2014). Native plants are the bee's knees: local and landscape predictors of bee richness and abundance in backyard gardens Urban Ecosyst. (2014) 17:641-659. DOI 10.1007/s11252-014-0349-0.

Parker, T. S., Nilon, C. H. (2008). Gray squirrel (Sciurus carolinensis) density, habitat suitability, and behavior in urban parks. Urban Ecosystems, 11, 243255.

Parker , T.S., Nilon, C. H. (2012). Urban landscape characteristics correlated with the synurbization of wildlife. Landscape and Urban Planning, 106 (2012) 316-325. http://dx.doi.org/10.1016/j.landurbplan.2012.04.003

Parker, F. D., Batra, S. W. T., V. J. Tepedino (1987) New pollinators for our crops. Agric. Zool. Rev. 2: 279-304

Pawelek, J.C., Frankie, G.W., Thorp, R.W., Przybylski, M. (2009) Modification of a community garden to attract native bee pollinators in urban San Luis Obispo, California. Cities Environ 2:1-20

Quinn, T. (1992). The distribution, movements, and diet of coyotes in urban areas of western Washington. Ph.D. Dissertation, University of Washington, Seattle.

Richardson D.M., Pyšek P., Rejmánek M., Barbour M.G., Panetta F.D. \& West C.J. 2000. Naturalization and invasion of alien plants: concepts and definitions. Diversity and Distributions 6: 93-107. https://doi.org/10.1046/j.1472-4642.2000.00083.x

Sarah J., Selmer A., James, A., Rye, A., Elizabeth Malone B., Danielle Fernandez, C., Kathryn, T. (2014). What Should We Grow in Our School Garden to Sell at the Farmers' Market? Initiating Statistical Literacy through Science and MathematicsIntegration. Science Activities: Classroom Projects and Curriculum. 51:17-32.

Shackleton, C. (2016). Do indigenous street trees promote more biodiversity than alien ones? Evidence using mistletoes and birds in South Africa. Forests, 7 (2016), p. 134

Sheaffer C, Rose MA (1998). The Native Plants of Ohio. Bulletin Extension, pp. 865-898. THE Ohio State University.

Sheskin, D. 2011. Handbook of Parametric and Nonparametric Statistical Procedures Test, Chapman and Hall/CRC, Fifth Edition, S.800.

Sjöman, H., Morgenroth, J., Sjöman, J.D., Sæbø, A., Kowarik, I. (2016) Diversification of the urban forest-Can we afford to exclude exotic tree species? Urban For. Urban Green., 18 (2016), pp. 237-241

Slattery, Britt E., Kathryn Reshetiloff, and Susan M. Zwicker. (2003). Native Plants for Wildlife, Habitat and Conservation Landscaping: Chesapeake Bay Watershed. U.S. Fish \& Wildlife Service, Chesapeake Bay Field Office, Annapolis, MD. 82 pp.

SNR, 2011. A Guide to Native Landscaping in Missouri. Landscaping with Native Plants. A Gardener's Guide for Missouri. (Chapter Four). 37pp. SHAW a division of the Missouri Botanical Garden. www.shawnature.org

Spaethe, J., J. Tautz and L. Chittka (2001) Visual constraints in foraging bumblebees: flower size and colour affect search time and flight behaviour. PNAS 98 (7): 3898-3903

Waser, N.M. and M. V. Price (1985) The effect of nectar guides on pollinator preference: experimental studies with a montane herb. Oecologia 67:121-126 Willmer, P. G. (2011) Pollination and Floral Ecology. Princeton University Press

Willmer, P. G. and G. N. Stone (2004) Behavioral, ecological and physiological determinants of the activity patterns of bees. Adv Study Behav 34: $347-466$ Zencirkıran, M. 2002. Geofitler. Uludağ Rotary Derneği Yayınları No:1 (ISBN 975-93004-0-0). Harman Ofset.İstanbul. 105 s.

Zencirkıran, M. 2004. Bursa Kent Peyzajında Kullanılan Bitki Türleri ve Bu Amaç için Kullanılabilecek Yerli ve Yabancı Orijinli Bitkilerin Saptanması. Uludağ Üniversitesi Bilimsel Araştırma Projeleri, Proje No: 2002/24. 307 s. (Sonuç Raporu).

Zencirkıran, M. 2009. Determination of Native Woody Landscape Plants in Bursa and Uludag. African J of Biotecn. 8: 5737-5746.

Zencirkıran, M. (2013). Peyzaj Bitkileri 1. (1.Basım). Nobel Akademik Yayıncılık, Yayın Numarası: 605, Fen Bilimleri Numarası:57, Ankara.475 s.

Zencirkıran, M., Altay Ender, E., Altun, G. (2019). A Research on Attractive Flowered Exotic Woody Landscape Plant Species Used in Urban Green Spaces in Bursa. (Chapter 1). Research in Landscape and Ornamental Plants (Edt. Murat Zencirkıran). Gece Kitaplığı/Gece Publishing. pp: 9-26. 
Zencirkıran, M., Seyidoğlu Akdeniz, N. (2017). Bursa Kent Parkları Odunsu Bitki Taksonlarının Ekolojik Tölerans Kriterleri Açısından Değerlendirilmesi . Bartın Orman Fakültesi Dergisi , 19 (2) , 11-19.

\section{Figures}

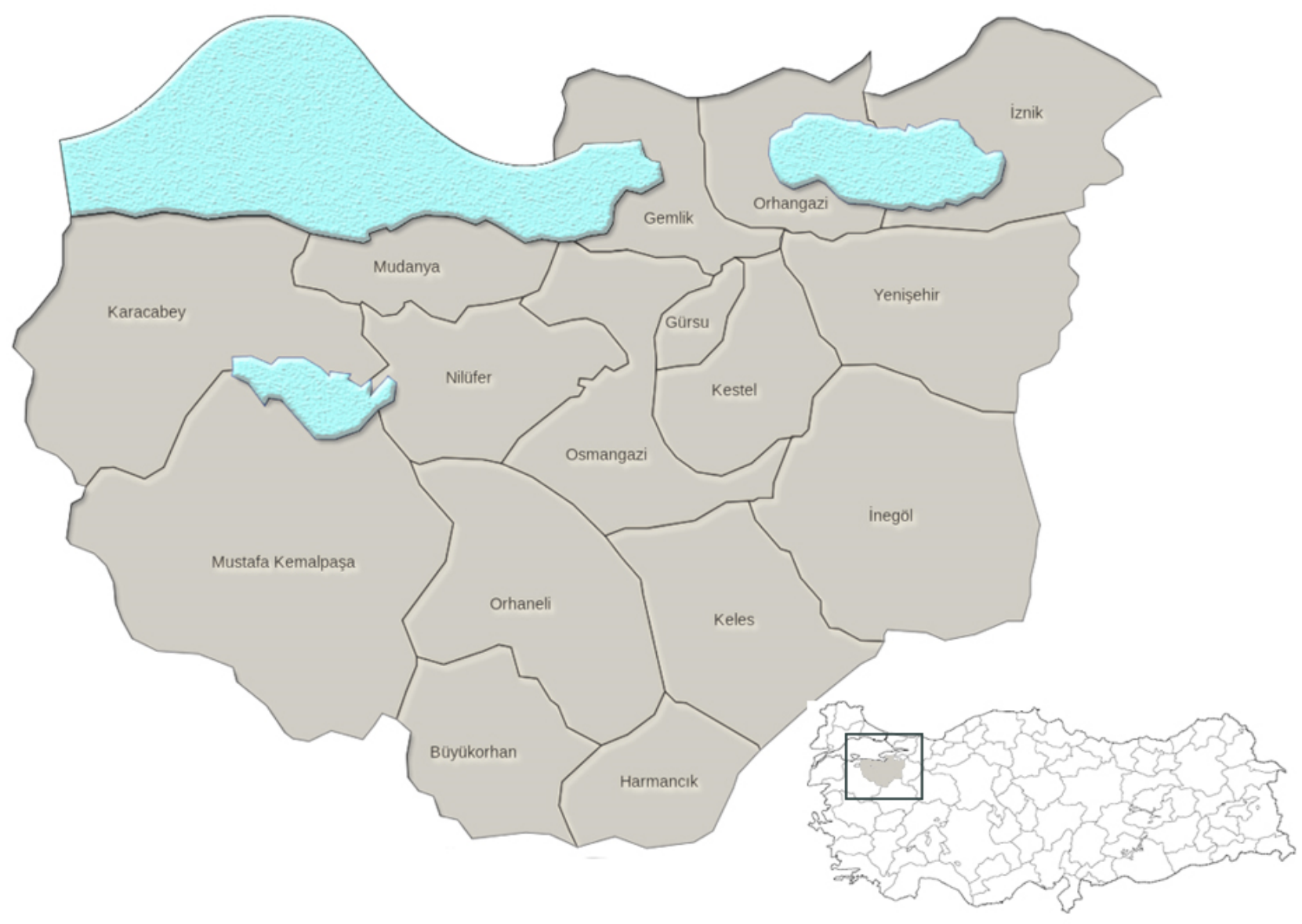

Figure 1

Location of the study area 


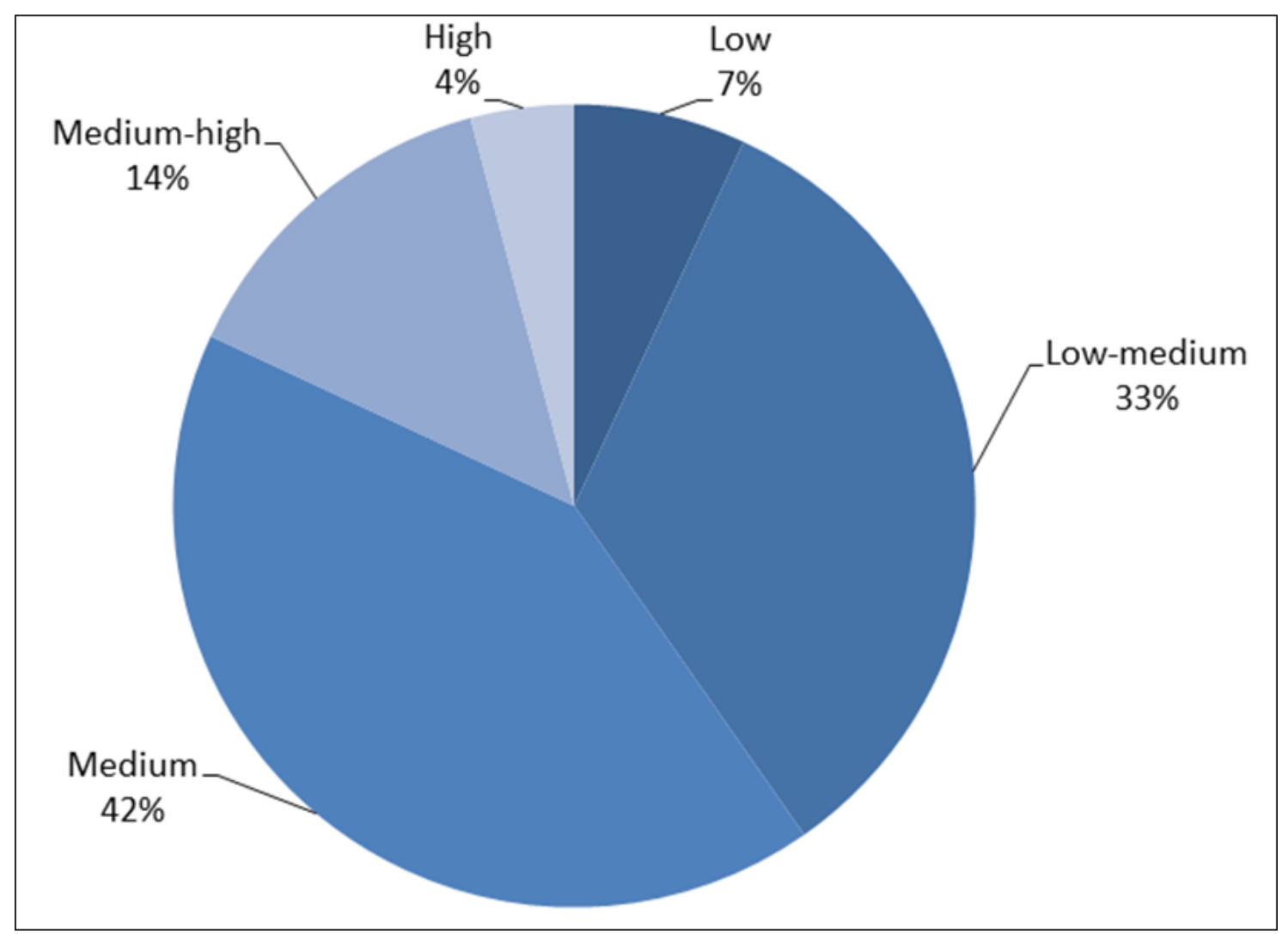

\section{Figure 2}

Distribution of the taxa according to their water demands

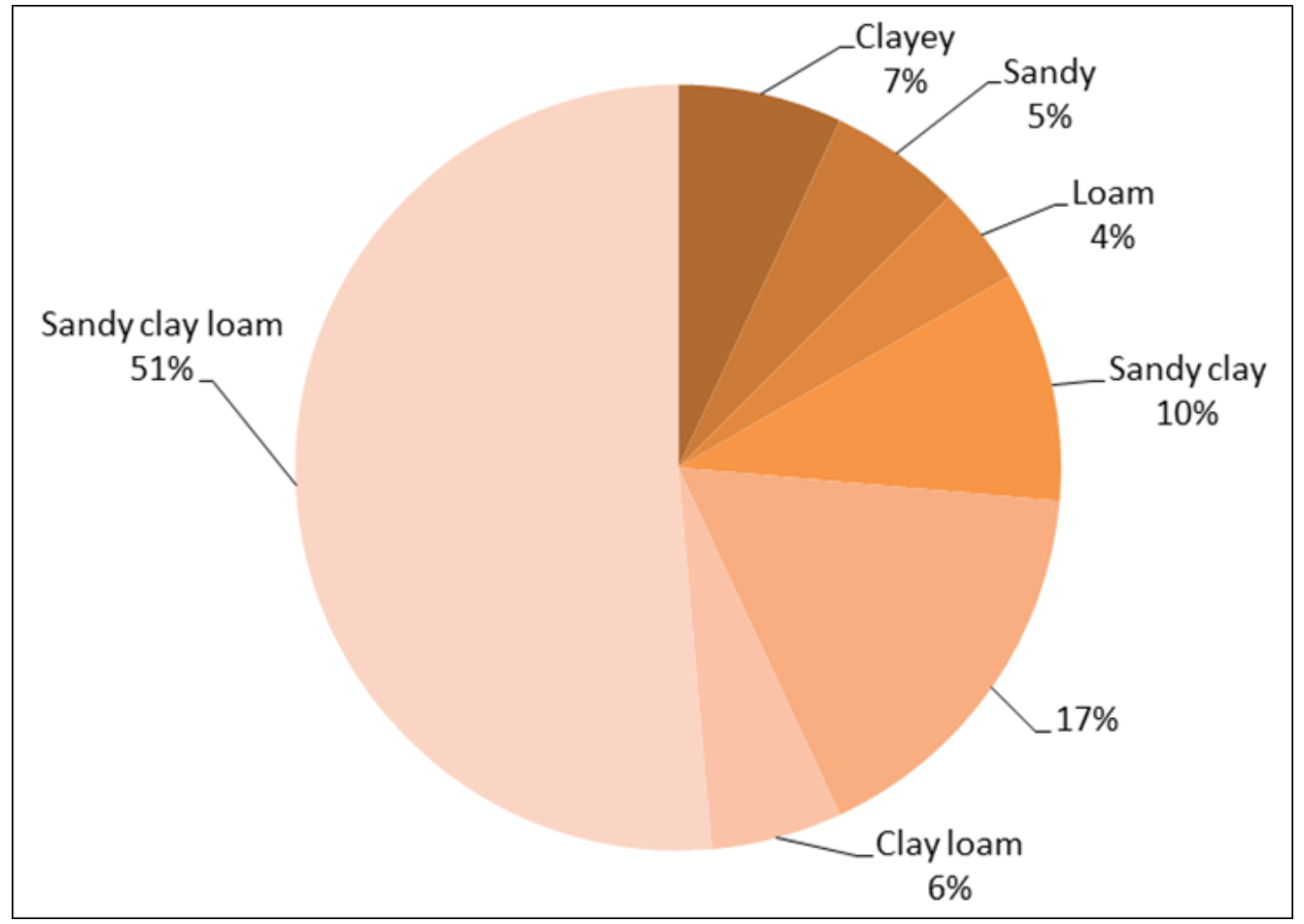

\section{Figure 3}

Distribution of the taxa according to their soil demands 


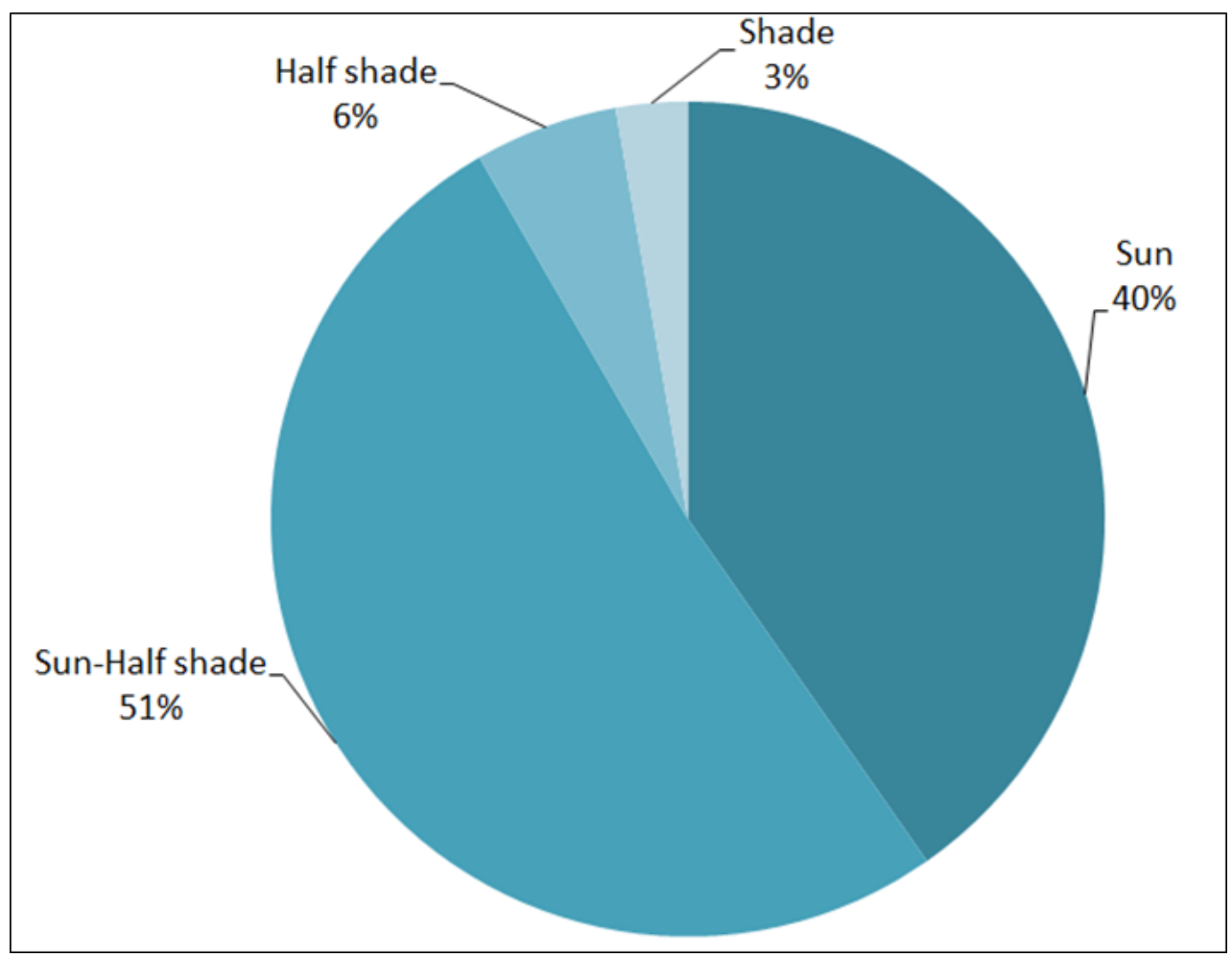

\section{Figure 4}

Distribution of the taxa according to their light demands

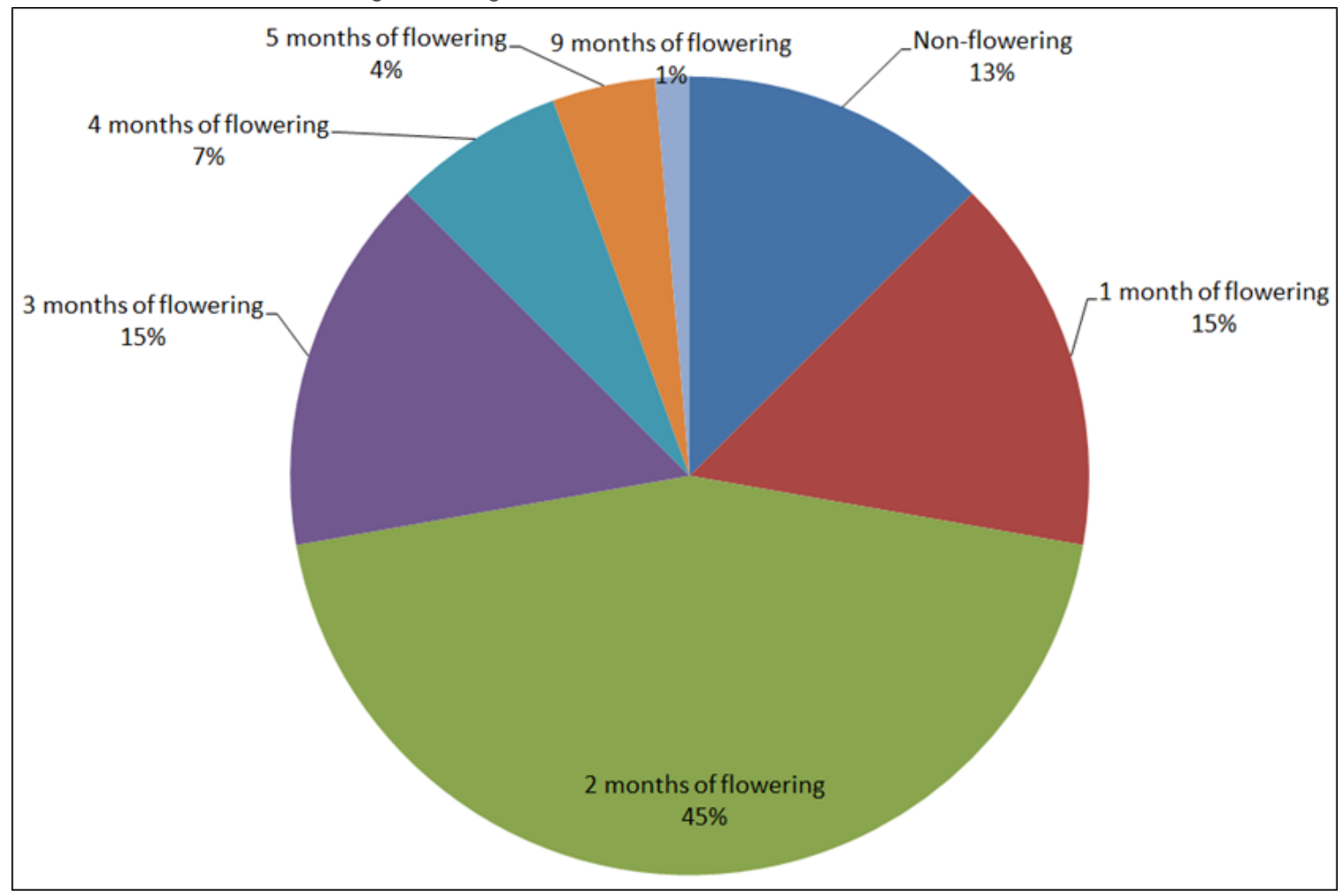

\section{Figure 5}

Distribution of the taxa according to their flowering times 


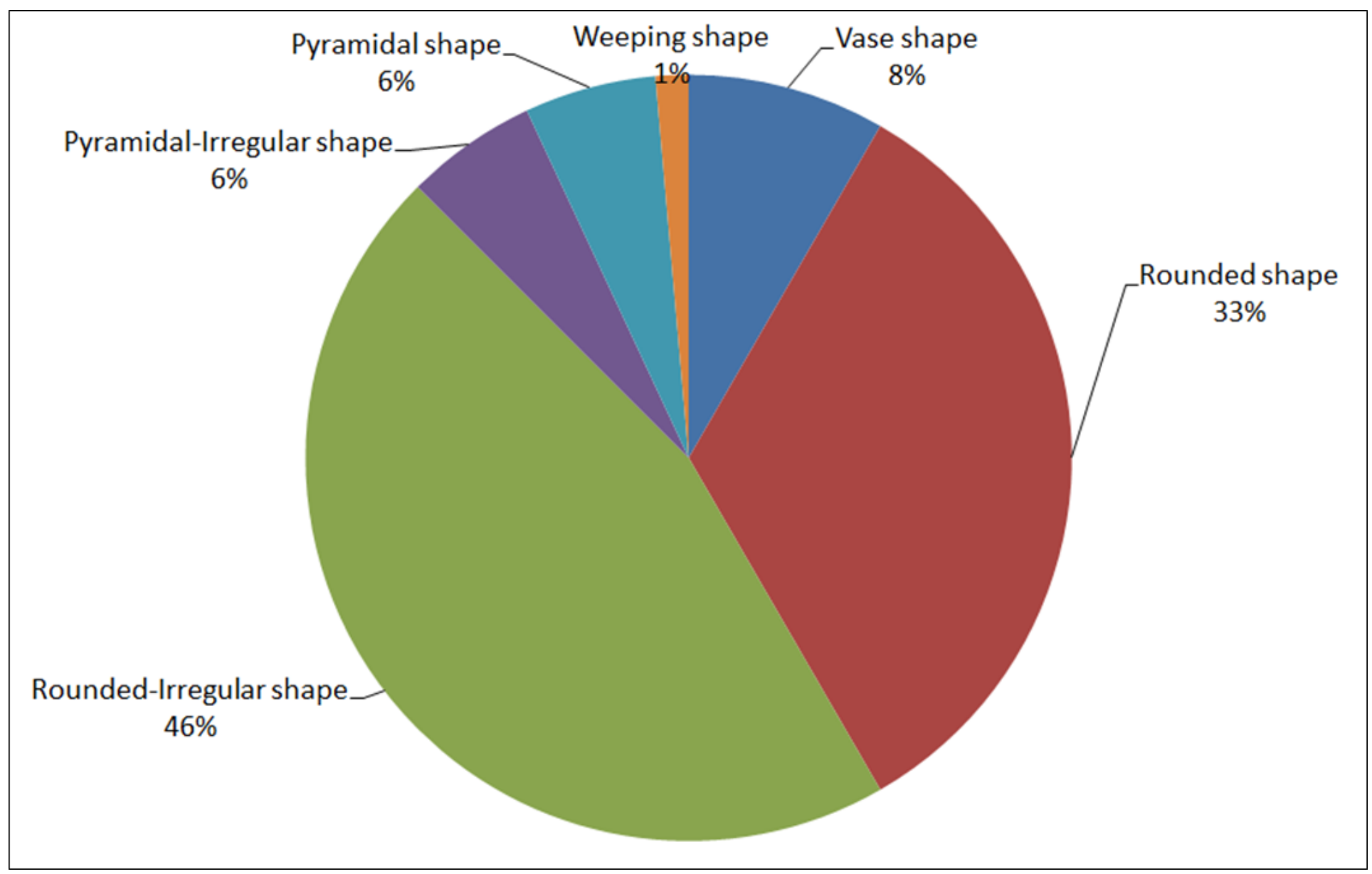

Figure 6

Distribution of the taxa according to their form characteristics 